\title{
Quantitation of artemether in pharmaceutical raw material and injections by high performance liquid chromatography
}

\author{
Isabela da Costa César*, Gerson Antônio Pianetti \\ Departamento de Produtos Farmacêuticos, Faculdade de Farmácia, Universidade Federal de Minas Gerais
}

\begin{abstract}
The quantitation of artemether in both pharmaceutical raw material and injections was carried out by high performance liquid chromatography (HPLC) with ultraviolet detection. A Zorbax $\mathrm{C}_{18}$ column $(150 \times 4.6 \mathrm{~mm} ; 5 \mu \mathrm{m})$, at $30^{\circ} \mathrm{C}$, and a mobile phase composed of acetonitrile and water (70:30), at a flow rate of $1 \mathrm{ml} / \mathrm{min}$, were used. The detection wavelength was $216 \mathrm{~nm}$ and the injection volume was $20 \mu \mathrm{L}$. The method proved to be linear $\left(r^{2}=0.9999\right)$, precise ( $R S D<20 \%$ for intra-day and inter-day precision), accurate and selective regarding possible impurities and excipients of the samples. The detection and quantitation limits were $8 \mu \mathrm{g} / \mathrm{mL}$ and $25 \mu \mathrm{g} / \mathrm{mL}$, respectively. The artemether content obtained in the raw material analysis was $99.26 \%$ and in the injections, $102.08 \%$. The optimized and validated method may be successfully employed to perform routine quality control analyses.
\end{abstract}

Uniterms: Artemether/quantitation. High performance liquid chromatography/quantitative analysis. Antimalarials.

\begin{abstract}
A quantificação de artemeter em matéria-prima farmacêutica e solução injetável foi realizada por cromatografia líquida de alta eficiência (CLAE) com detecção na região do ultravioleta. Empregou-se coluna Zorbax $\mathrm{C}_{18}(150 \times 4.6 \mathrm{~mm} ; 5 \mu \mathrm{m})$, mantida a $30^{\circ} \mathrm{C}$, e fase móvel composta por acetonitrila e água (70:30), com fluxo de $1 \mathrm{ml} / \mathrm{min}$. A detecção foi realizada a $216 \mathrm{~nm}$, e o volume de injeção foi $20 \mu 1$. O método se mostrou linear $\left(\mathrm{r}^{2}=0,9999\right)$, preciso ( $\mathrm{DPR}<2,0 \%$ para precisão intra-dia e inter-dias) e seletivo em relação a possíveis impurezas e excipientes das amostras. Os limites de detecção e quantificação obtidos foram $8 \mu \mathrm{g} / \mathrm{mL}$ e $25 \mu \mathrm{g} / \mathrm{mL}$, respectivamente. O teor médio de artemeter obtido na análise da matéria-prima farmacêutica foi $99,26 \%$ e na solução injetável, 102,08\%. O método otimizado e validado pode ser utilizado com sucesso para análises rotineiras em controle de qualidade.
\end{abstract}

Unitermos: Artemeter/quantificação. Cromatografia líquida de alta eficiência/análise quantitativa. Antimaláricos.

\section{INTRODUCTION}

Malaria is the world's most important parasitic infection and effective control of this disease poses a great challenge to the public health sector in poor countries (Guerin et al., 2002). The incidence of malaria worldwide is estimated to be 300-500 million clinical cases each year, with around $90 \%$ of these occurring in Africa, mostly caused by Plasmodium falciparum. Malaria is thought to kill between 1.1 and 2.7 million people worldwide each year, about one million of whom are African children under the

\footnotetext{
*Correspondence: I. C. César. Departamento de Produtos Farmacêuticos, Faculdade de Farmácia, Universidade Federal de Minas Gerais, Av. Pres. Antônio Carlos, 6627, 31270-901 - Belo Horizonte - MG, Brasil. E-mail: isaccesar@bol.com.br
}

age of five (World, 2000). Due to the widespread P. falciparum resistance to conventional antimalarial drugs, many countries have been facing difficulties in effective malaria control and treatment. Currently, there are reported cases of resistance to all classes of antimalarials, except to artemisinin and its derivatives (Wongsrichanalai et al., 2002).

Artemether, also called dihydroartemisinin methyl ether (Figure 1), is a synthetic derivative of artemisinin, widely used in malaria treatment in endemic areas. This drug can be administered as an oily solution by intramuscular injection, or in tablets orally (Karbwang et al., 1997). In addition, artemether can be associated with lumefantrine, in fixed-dose combination tablets containing $20 \mathrm{mg}$ of artemether and $120 \mathrm{mg}$ of lumefantrine, as a first-line therapy in the treatment of falciparum malaria in Brazil (Brasil, 2006). 


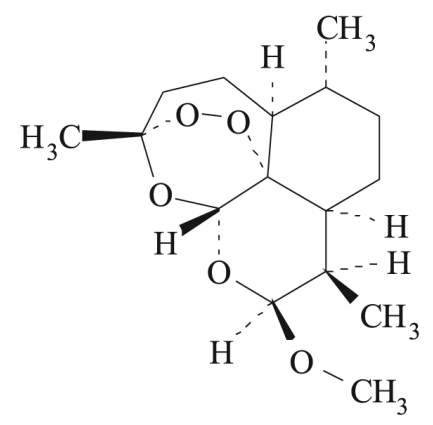

FIGURE 1 - Chemical structure of artemether.

In spite of increasing artemether use in treating malaria within endemic areas, the scientific literature is still limited regarding analytical methods aimed at quantitation of the drug in pharmaceutical products, and in quality evaluations of the available formulas. The International Pharmacopeia (2006) presents monographs of artemether raw material and injection forms. The assay methods of these products are high performance liquid chromatography (HPLC) with ultraviolet detection $(216 \mathrm{~nm})$, and an alternative method in which artemether is submitted to acid hydrolysis, followed by detection in UV spectrophotometer, at $254 \mathrm{~nm}$.

The quantitation of artemether in pharmaceutical products was described by Atemnkeng et al. (2007a), who performed the determination of artemisinin derivatives in medicines used in Kenya and Congo, while in a second study, Atemnkeng et al. (2007b) quantified artemether, methylparaben and propylparaben in a dry suspension pediatric formulation. César et al. (2008) carried out the simultaneous quantitation of artemether and lumefantrine in fixed-dose combination tablets. Each of these studies employed high performance liquid chromatography with ultraviolet detection in the artemether quantitation. There are no currently available studies on the quantitative determination of artemether in pharmaceutical raw material or in injections, employed in the treatment of malaria patients in Brazil.

Therefore, the aim of the present work was the quantification of artemether in pharmaceutical raw material and injection forms. The method described in the International Pharmacopeia (4 ed.) was adapted for the analysis, and the parameters of linearity, intra-day precision, inter-day precision, accuracy and selectivity were validated. The optimized method was employed to evaluate the quality of the artemether injections currently used for treating malaria in Brazil.

\section{MATERIAL AND METHODS}

\section{Reagents and material}

Artemether chemical reference substance (batch
10203215, purity $100.0 \%$ ) and raw material (batch 061010 4087ER) were purchased from Dafra Pharma (Turnhout, Belgium). Samples of artemether injection $(80 \mathrm{mg} / \mathrm{mL}-$ Cipla, batch ZD6375) were kindly donated by the Brazilian Health Ministry. Acetonitrile (HPLC grade) and isopropyl alcohol, acetone, chloroform and ether (analytical grade) were purchased from Tedia (Fairfield, OH, USA). Water was purified using a Millipore system (Bedford, MA, USA).

\section{Chromatographic conditions}

The HPLC analyses were carried out on an Agilent 1200 system (Palo Alto, CA, USA), composed of quaternary pump, autosampler, diode array detector (DAD) and HP ChemStation software. The column used was a Zorbax $\mathrm{C}_{18}(150 \times 4.6 \mathrm{~mm}$ i.d.; $5 \mu \mathrm{m}$ particle size $)$ from Agilent, maintained at $30{ }^{\circ} \mathrm{C}$. The mobile phase consisted of acetonitrile and water, at a flow rate of $1 \mathrm{ml} / \mathrm{min}$. Different proportions of these solvents were evaluated, aiming to optimize the retention time and peak symmetry. The optimized mobile phase was composed of $70 \%$ acetonitrile and $30 \%$ water. The detection was performed at $216 \mathrm{~nm}$ and the injection volume was $20 \mu \mathrm{L}$.

\section{Preparation of standard and sample solutions of artemether}

Standard solution: Approximately $20 \mathrm{mg}$ of artemether reference standard was accurately weighed, transferred to a $5 \mathrm{~mL}$ volumetric flask and diluted in mobile phase (acetonitrile:water - 70:30). The volume was adjusted with a mobile phase to a final concentration of $4 \mathrm{mg} / \mathrm{mL}$.

Sample solution of raw material: Approximately $100 \mathrm{mg}$ of artemether raw material, previously dried at $60{ }^{\circ} \mathrm{C}$ in a vacuum oven for three hours, were accurately weighed, transferred to a $25 \mathrm{~mL}$ volumetric flask and diluted in the mobile phase (acetonitrile:water-70:30). The volume was adjusted with mobile phase to a final concentration of $4 \mathrm{mg} / \mathrm{mL}$.

Sample solution of injection form: An aliquot of $5 \mathrm{~mL}$ of the artemether injection was transferred to a $100 \mathrm{~mL}$ volumetric flask. Several solvents were evaluated for miscibility with the injection, and the mixture of isopropyl alcohol and acetonitrile $(75: 25)$ proved to be an adequate dilution. The volume was adjusted with this solvent to a final concentration of $4 \mathrm{mg} / \mathrm{mL}$.

\section{Validation}

After optimization of the chromatographic conditions, the parameters of linearity, intra-day precision, 
inter-day precision, accuracy, selectivity, limit of detection and limit of quantitation were evaluated to validate the process, according to the specifications described in ANVISA Resolution RDC No. 899 (Brasil, 2003).

\section{Linearity}

Artemether stock solutions, at $8 \mathrm{mg} / \mathrm{mL}$, were prepared in acetonitrile, in triplicate. Aliquots of these solutions were diluted in the mobile phase to five different concentrations. The evaluated linear range was from 50 to $150 \%$ of the test concentration, which corresponds to the concentration range from 2 to $6 \mathrm{mg} / \mathrm{mL}$ of artemether. The analytical curve with peak area versus artemether concentration was plotted and the obtained data were subjected to regression analysis.

\section{Precision}

The intra-day precision was evaluated by means of six determinations at $100 \%$ of test concentration $(4 \mathrm{mg} /$ $\mathrm{ml}$ ), for both the raw material and injections. Artemether sample solutions were prepared as previously described. To evaluate the inter-day precision, the same procedure was adopted, performing the analyses over two consecutive days. In each analysis, the artemether content and the relative standard deviation (RSD) were calculated.

\section{Accuracy}

The accuracy was evaluated by the standard addition method and known amounts of the reference standard were added to the artemether injection. Artemether standard solutions, at three different concentrations, were added to the injection to give final concentrations of $3 \mathrm{mg} / \mathrm{mL}$, $4 \mathrm{mg} / \mathrm{mL}$ and $5 \mathrm{mg} / \mathrm{mL}$, corresponding to $75 \%, 100 \%$ and $125 \%$ of the test concentration, respectively. At each concentration, the solutions were prepared in triplicate and the recovery was calculated.

\section{Selectivity}

The selectivity of the chromatographic method was determined by evaluation of the spectral purity of the artemether peaks obtained in chromatograms of both standard and sample solutions. This test was performed by means of overlapping ultraviolet spectra obtained at different points of the chromatographic peak, in order to verify whether other substances co-eluted at the same retention time of the artemether peak.

\section{Limits of detection (LOD) and quantitation (LOQ)}

These limits were calculated using the analytical curve parameters (standard deviation of intercept and slope), according to the equations described in Resolution RDC No. 899 (Brasil, 2003).

\section{Analyses of artemether raw material and injection}

Samples of artemether raw material and injection were analyzed using the optimized and validated HPLC method. The solutions for analysis were prepared following the previously described procedure. The artemether mean content and relative standard deviation (RSD) were determined in each analyzed sample.

\section{RESULTS AND DISCUSSION}

Initially, the artemether spectrum in the ultraviolet region was obtained in the range of 200 to $400 \mathrm{~nm}$ using

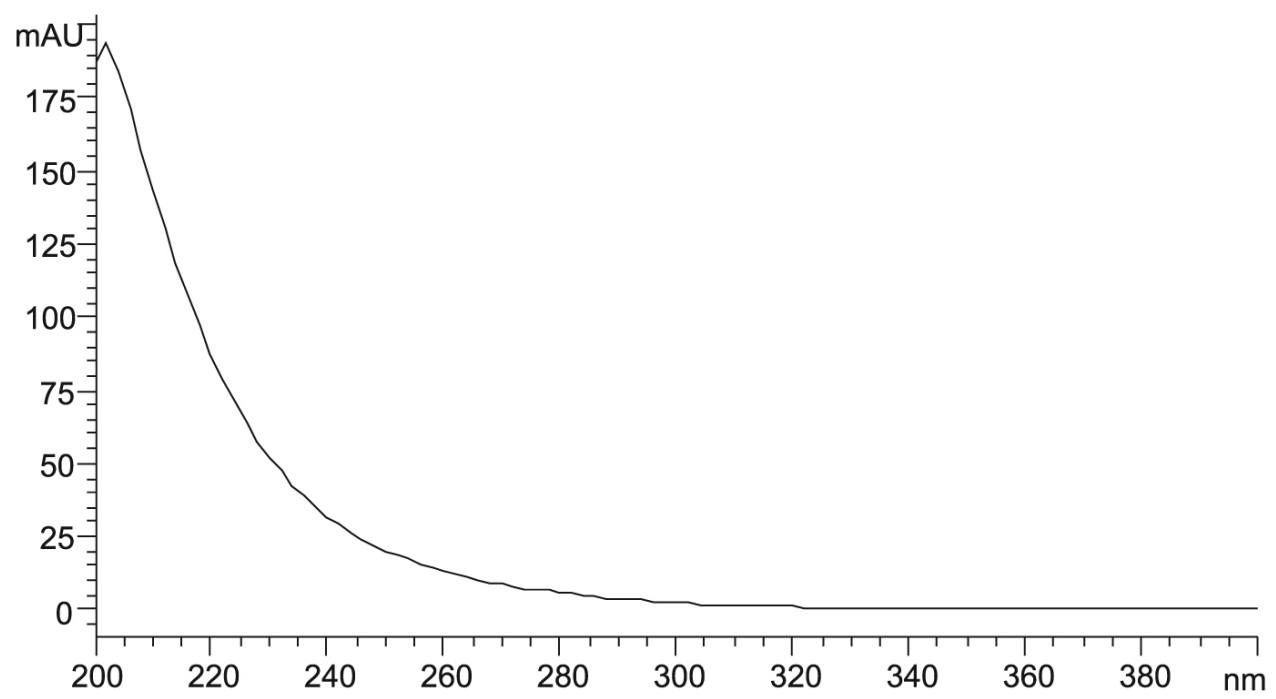

FIGURE 2 - Ultraviolet spectrum obtained at DAD, using an artemether solution at $4 \mathrm{mg} / \mathrm{mL}$ in mobile phase, injection volume of $20 \mu \mathrm{L}$. 
the diode array detector (DAD) of the chromatograph with a solution at $4 \mathrm{mg} / \mathrm{mL}$ in the mobile phase. The maximum absorption wavelengths were verified, as well as the artemether absorptivity in the ultraviolet region (Figure 2).

According to the obtained spectrum, artemether absorbs only in the initial ultraviolet region. Thus, the artemether detection is possible at $216 \mathrm{~nm}$. However, considering its low molar absorptivity, the concentration of the solutions used in the analyses must be considerably high. Following the procedure described in International Pharmacopeia (4 ed.), it is necessary to use standard and sample solutions containing $10 \mathrm{mg} /$ $\mathrm{mL}$ of artemether. In this study, the artemether concentration used was $4 \mathrm{mg} / \mathrm{mL}$. At this concentration, the artemether peak presents the adequate intensity required for integration and quantitation, while reducing the consumption of artemether reference standard for the preparation of the solution.

Some adaptations in the chromatographic conditions described in International Pharmacopeia were carried out for the quantitation of artemether in the raw material and injection. In the pharmacopeia procedure, the length of the chromatographic column should be $250 \mathrm{~mm}$ with an acetonitrile concentration of $62 \%$ in the mobile phase. For the purpose of reducing the analyses time, and to improve the peak symmetry, the column length was reduced to $150 \mathrm{~mm}$ and the acetonitrile concentration was increased to $70 \%$. Under these conditions, it was possible to obtain a symmetric peak, with a tailing factor of 1.25 and retention time of 6.70 minutes (Figure 3).

Some problems regarding the preparation of the injection sample solution were experienced. According to the procedure described in International Pharmacopeia (2006), the injection should be quantitatively diluted in the mobile phase, resulting in a diluted solution at the desired concentration. However, since the artemether injection is highly oily and immiscible with the mobile phase and with pure acetonitrile, the execution of this procedure resulted in the separation of the solution in two phases. The miscibility of the artemether injection with several solvents was then evaluated, and it was verified that the injection was miscible only with organic solvents, such as acetone, chloroform, ether or isopropyl alcohol.

As isopropyl alcohol also showed adequate miscibility with the employed mobile phase, this solvent was selected for the dilution. The proportion of isopropyl alcohol in acetonitrile was evaluated, and a diluent constituted of $75 \%$ isopropyl alcohol and $25 \%$ acetonitrile proved to be adequate for the dilution of the injection, and for the subsequent analyses in the chromatograph.

\section{Validation}

Linearity

The resulting analytical curve indicated an adequate linear correlation between the artemether concentrations and the peak areas, in the range of 2 to $6 \mathrm{mg} / \mathrm{mL}$. Data from the regression analysis are demonstrated in Table I. The regression coefficient $\left(r^{2}=0.9999\right)$ indicated that, in the evaluated concentration range, the peak areas were directly proportional to the artemether concentrations and, thus, the method presented adequate linearity. The RSD value lower than $2.0 \%$ demonstrated the precision of the analytical curve.

TABLE I - Results of the regression analyses obtained for the HPLC method of artemether quantitation

\begin{tabular}{ll}
\hline Regression parameters & Results \\
\hline Regression coefficient $\left(r^{2}\right)$ & 0.9999 \\
Slope \pm standard deviation & $32237 \pm 26$ \\
Intercept \pm standard deviation & $6.89 \pm 2.780$ \\
Relative standard deviation $(\%)$ & 0.06 \\
Concentration range $(\mathrm{mg} / \mathrm{mL})$ & $2-6$ \\
Number of points & 5 \\
\hline
\end{tabular}

\section{Precision}

The intra-day precision of the HPLC method was evaluated by means of six determinations at $100 \%$ of the test concentration $(4 \mathrm{mg} / \mathrm{ml})$. In the analyses of artemether in the raw material, the RSD values for intra-day $(n=6)$ and inter-days $(n=12)$ precision were $0.49 \%$ and $0.48 \%$, respectively. For the injection, the values were $1.31 \%$ and $0.89 \%$ for the intra-day and inter-days precision, respectively. Thus, precision was demonstrated for both samples, since all the obtained RSD values were lower than $2.0 \%$.

Accuracy: Accuracy was evaluated by the standard addition method, at three different concentrations. The recovery obtained at concentrations of $3 \mathrm{mg} / \mathrm{mL}$, $4 \mathrm{mg} / \mathrm{mL}$ and $5 \mathrm{mg} / \mathrm{mL}$ were $100.17 \%, 99.59 \%$ and $100.90 \%$, respectively. The mean recovery was $100.22 \%$, proving the accuracy of the HPLC method.

\section{Selectivity}

The determination of the spectral purity of the artemether chromatographic peaks was performed in the DAD detector. The peak purities obtained from solutions of artemether standard, raw material and injection were $99.95 \%$, $99.99 \%$ and $99.93 \%$, respectively. The high peak purity values suggest that other substances did not co-elute with the artemether peak, and that the method is selective for the quantitation of artemether in raw material and injection. 


\section{Limits of detection (LOD) and quantitation (LOQ)}

The determination of these limits was carried out using an equation that considers the parameters of the analytical curve. The resulting LOD and LOQ values were $8 \mu \mathrm{g} / \mathrm{mL}$ and $25 \mu \mathrm{g} / \mathrm{mL}$, respectively. Due to the low absorptivity of artemether in the ultraviolet region, the LOD and LOQ were relatively high, however, these values are sufficient for the quantitation of the artemether solutions in the test concentration used in this study.

The results obtained in the validation process of the HPLC method are summarized in Table II.

\section{Analyses of artemether raw material and injection}

The optimized and validated method was applied to the quantitation of artemether in pharmaceutical raw material and injection. The mean content of the analyzed
TABLE II - Results of the validation process of the HPLC method for artemether quantitation

\begin{tabular}{ll}
\hline Validation parameters & Results \\
\hline Intra-day precision & \\
$\quad$ Raw material - RSD & $0.49 \%$ \\
$\quad$ Injection - RSD & $1.31 \%$ \\
Inter-days precision & \\
$\quad$ Raw material - RSD & $0.48 \%$ \\
$\quad$ Injection - RSD & $0.89 \%$ \\
Accuracy & \\
$\quad$ Mean recovery & $100.22 \%$ \\
Selectivity - peak spectral purity & \\
$\quad$ Standard & $99.95 \%$ \\
$\quad$ Raw material & $99.99 \%$ \\
$\quad$ Injection & $99.93 \%$ \\
Limit of detection & $8 \mu \mathrm{g} / \mathrm{mL}$ \\
Limit of quantitation & $25 \mu \mathrm{g} / \mathrm{mL}$ \\
\hline
\end{tabular}
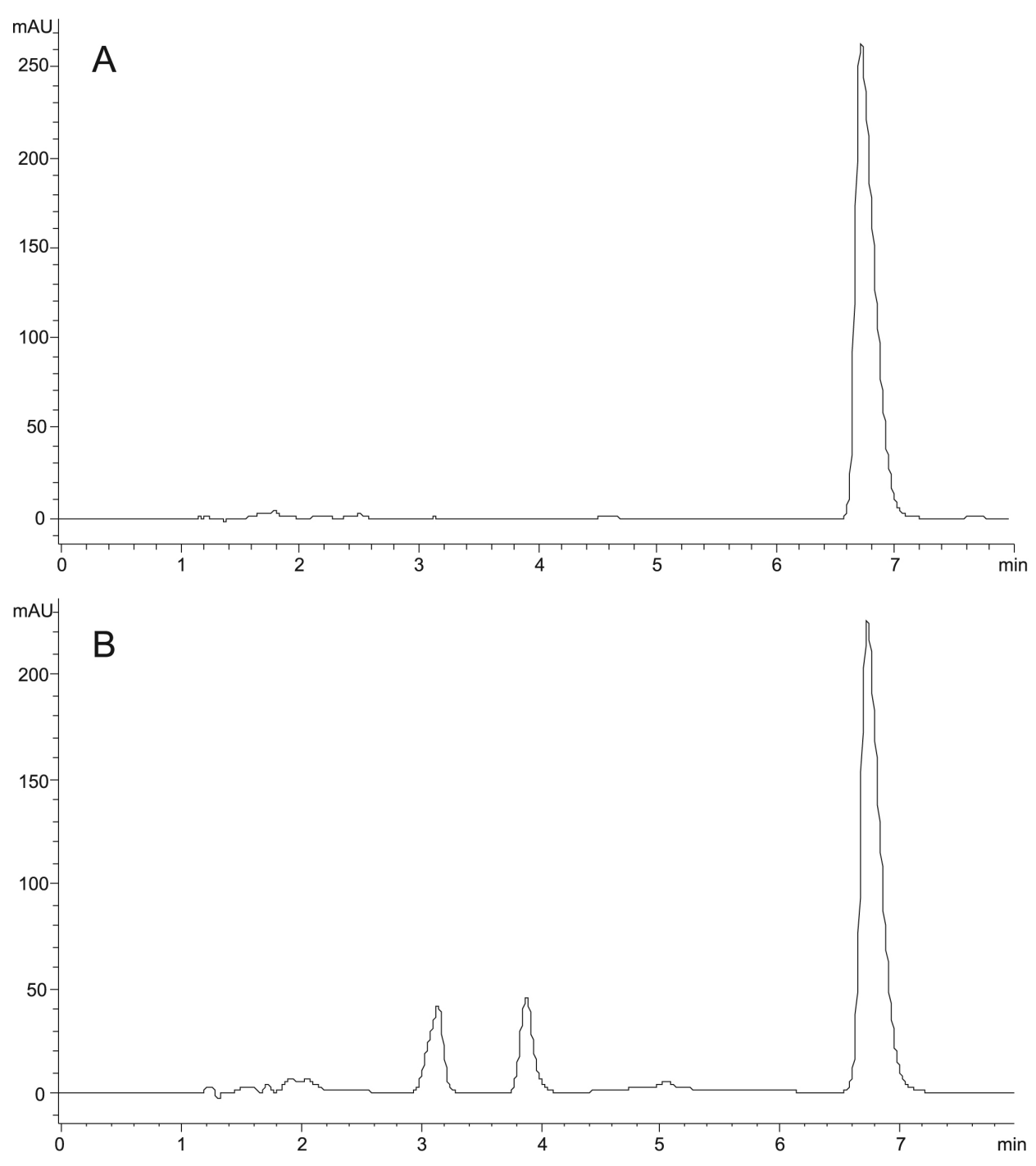

FIGURE 3 - HPLC chromatograms obtained in a Zorbax $\mathrm{C}_{18}(150 \times 4.6 \mathrm{~mm}, 5 \mu \mathrm{m})$ column, at $30^{\circ} \mathrm{C}$, mobile phase composed of acetonitrile and water (70:30), flow rate of $1 \mathrm{~mL} / \mathrm{min}$ and detection at $216 \mathrm{~nm}$. Samples of artemether: (A) raw material; (B) injection. 
raw material was $99.26 \%$, while for the injection, the content was $102.08 \%$. The chromatograms obtained in the analyses of the raw material and injections are demonstrated in Figure 3.

In both chromatograms, the artemether peak was eluted at 6.70 minutes. For the injection, two other peaks are evident in the chromatogram. The first peak at $3.15 \mathrm{mi}-$ nutes is probably related to the oil or other excipients of the formulation. The second peak at 3.90 minutes corresponds to the isopropyl alcohol used in the sample preparation. The identity of the peaks was confirmed by the ultraviolet spectra obtained from the DAD. In each analysis, a chromatographic resolution between the peaks of artemether and isopropyl alcohol, or excipients, was achieved.

\section{CONCLUSION}

The optimized and validated HPLC method was shown to be adequate for the quantitation and quality evaluation of artemether in both pharmaceutical raw material and injections, and can be successfully used for routine quality control analyses. Considering the increasing use of artemether to treat malaria in endemic areas, the availability of simple and rapid analytical methods is essential to evaluate the quality of formulas being used currently.

\section{AKNOWLEDGMENTS}

The authors would like to thank Brazilian Health Ministry, for the artemether injection donation, and the Brazilian Pharmacopeia, for financial support.

\section{REFERENCES}

ATEMNKENG, M.A.; COCK, K.; PLAIZIER-VERCAMMEN, J. Quality control of active ingredients in artemisininderivative antimalarials within Kenya and DR Congo. Trop. Med. Int. Health, v.12, p.68-74, 2007a.

ATEMNKENG, M. A.; MARCHAND, E.; PLAIZIERVERCAMMEN, J. Assay of artemether, methylparaben and propylparaben in a formulated paediatric antimalarial dry suspension. J. Pharm. Biomed. Anal., v.43, p.727-732, $2007 b$.
BRASIL. Ministério da Saúde. Agência Nacional de Vigilância Sanitária. Legislação. VisaLegis. Resolução RDC n.899, de 29 de maio de 2003. Guia de validação de métodos analíticos e bioanalíticos. Avaiable at: $<\mathrm{http}$ ://e-legis.bvs.br/ leisref/public/showAct.php?id=15132\&word=>. Accessed on: 28 abr. 2006.

BRASIL. Ministério da saúde. Secretaria de Vigilância em Saúde. Programa Nacional de Controle da Malária. Esquemas recomendados para o tratamento da malária não complicada no Brasil. Brasília: Ministério da saúde, 2006. p.1-4.

CÉSAR, I. C.; NOGUEIRA, F. H. A.; PIANETTI, G. A. Simultaneous determination of artemether and lumefantrine in fixed dose combination tablets by HPLC with UV detection. J. Pharm. Biomed. Anal., v.48, p.951-954, 2008.

GUERIN, P. J.; OLLIARO, P.; NOSTEN, F.; DRUILHE, P.; LAXMINARAYAN, R.; BINKA, F.; KILAMA, W. L.; FORD, N.; WHITE, N. J. Malaria: current status of control, diagnosis, treatment, and a proposed agenda for research and development. Lancet Infect. Dis., v.2, p.564-573, 2002.

INTERNATIONAL Pharmacopoeia. 4.ed. Geneva: World Health Organization, 2006. 1499 p.

KARBWANG, J.; NA-BANGCHANG, K.; CONGPUONG, K; MOLUNTO, P.; THANAVIBUL, A. Pharmacokinetics and bioavailability of oral and intramuscular artemether. Eur. J. Clin. Pharmacol., v.52, p.307-310, 1997.

W ONGSRICHANALAI, C.; PICKARD, A. L.; WERNSDORFER, W. H.; MESHNICK, S. R. Epidemiology of drug-resistant malaria. Lancet Infect. Dis., v.2, p.209-218, 2002.

WORLD Health Organization. WHO Expert Committee on Malaria. Twentieth Report. WHO Technical Report Series, 892. Geneva, 2000. Avaiable at: $<$ http://www.who.int/ malaria/docs/ecr20 toc.htm>. Accessed on: 24 abr. 2006.

Received for publication on $12^{\text {th }}$ September 2008 . Accepted for publication on $01^{\text {st }}$ April 2009. 